\title{
Digestion of Feed Amino Acids in the Rumen and Intestine of Steers Measured Using a Mobile Nylon Bag Technique
}

\author{
A. Taghizadeh, ${ }^{1, *}$ M. Danesh Mesgaran, ${ }^{1}$ R. Valizadeh, ${ }^{1}$ \\ F. Eftekhar Shahroodi, ${ }^{1}$ and K. Stanford ${ }^{2}$ \\ ${ }^{1}$ Department of Animal Science, Faculty of Agriculture, Ferdowsi University of Mashad, Iran 91775-1163 \\ ${ }^{2}$ Alberta Agriculture, Food and Rural Development, Lethbridge, Alberta, Canada T1J 4V6
}

\begin{abstract}
The disappearance of dry matter (DM), crude protein (CP), and amino acids (AA) in steers after rumen incubation and intestinal passage of alfalfa hay, barley hay, corn silage, barley grain, corn grain, wheat bran, meat meal, fish meal, cottonseed meal, and soybean meal were measured in 3 steers using a mobile nylon bag technique. Ruminal degradation of individual AA differed between feedstuffs. For barley hay and corn silage, the ruminal disappearance of total AA was higher and lower than the other feedstuffs, respectively. The intestinal digestibility of total AA in alfalfa hay was lower than the digestion of $\mathrm{CP}$. The intestinal digestibility of Arg and His was higher than that of total AA in alfalfa hay, meat meal, cottonseed meal, soybean meal, barley hay, and wheat bran. In addition, the intestinal digestibility of Lys was higher than that of total AA in alfalfa hay, meat meal, cottonseed meal, soybean meal, barley hay, corn silage, and wheat bran. The intestinal disappearance of CP in most cases was higher than that of DM. The results indicated that feedstuffs with lower ruminal disappearance of DM, CP, total AA, essential $\mathrm{AA}$, and nonessential AA generally had a higher intestinal disappearance, resulting in a relatively constant total tract disappearance. These results could be used to improve the current system of diet formulation in ruminants.
\end{abstract}

(Key words: dry matter, crude protein, amino acid, mobile bag)

Abbreviation key: $\mathbf{A H}=$ alfalfa hay, $\mathbf{B G}=$ barley grain, $\mathbf{B H}=$ barley hay, $\mathbf{C G}=$ corn grain, $\mathbf{C S}=$ corn silage, $\mathbf{C S M}=$ cottonseed meal, EAA $=$ essential AA, $\mathbf{F M}=$ fish meal, $\mathbf{M M}=$ meat meal, NEAA = nonessential AA, SBM = soybean meal, $\mathbf{W B}=$ wheat bran.

Received August 18, 2004.

Accepted February 15, 2005.

Corresponding author: Akbar Taghizadeh; e-mail: ataghius2000 @yahoo.com.

*Current address: Department of Animal Science, Faculty of Agriculture, University of Tabriz, Iran 51664.

\section{INTRODUCTION}

Modern protein evaluation systems for ruminants describe the supply and requirement of true protein that can be absorbed from the small intestine (Van Straalen et al., 1997). To increase the efficiency by which this true protein is used for production purposes, research has focused on the requirement of the first limiting AA, often Lys or Met (Schwab et al., 1992), with results incorporated into protein evaluation systems (Rulquin and Verite, 1993; Van Straalen et al., 1997). Amino acids available for absorption from the small intestine are primarily the sum of microbial protein synthesized in the rumen by microorganisms and dietary protein that has escaped rumen degradation (Harstad and Prestløkken, 2001). Many studies have shown no response to the increase of dietary CP levels in high performance dairy cattle (Chiou et al., 1995; Van Straalen et al., 1997). This lack of response to increased dietary $\mathrm{CP}$ may be due to excess protein in the diet, imbalance in AA preventing a response (Abu-Ghazealeh et al., 2001), or nitrogen in the rumen derived from the breakdown of preformed dietary protein in excess of maximal capability of the microbial mass to synthesis protein (Chiou et al., 1995). However, the development of precise information of the metabolism of protein and AA in the total tract of ruminant animals is exceedingly difficult because of the complexities in the metabolism of protein and AA in the rumen (Von Keyserlingk et al., 1998). Because of degradation of protein in the rumen by microbes, the AA profile that escapes the rumen and enters the duodenum differs considerably from the AA composition of the feed consumed (Piepenbrink and Schingoethe, 1998). Therefore, the fate of dietary AA degraded in the rumen and the amount of subsequent digestion in the small intestine requires further evaluation. However, the effect of rumen fermentation on the AA digestion and profile of undegraded protein is not clear, because some studies found no effect (Varvikko et al., 1983; Messman et al., 1992), whereas others reported different effects for different feedstuffs (Rooke, 1985; Susmel et al., 1989). The effect of rumen fermentation and small intestinal digestion on the AA profile 
of feed protein can be studied using the rumen nylon bag and mobile nylon bag techniques (Van Straalen et al., 1993). The objective of this experiment was to determine the $\mathrm{DM}, \mathrm{CP}$, and $\mathrm{AA}$ disappearance from alfalfa hay (AH), barley hay (BH), corn silage (CS), barley grain (BG), corn grain (CG), wheat bran (WB), meat meal (MM), fish meal (FM), cottonseed meal (CSM), and soybean meal (SBM) in the rumen, small intestine, and total tract using the rumen in situ and mobile nylon bag technique.

\section{MATERIALS AND METHODS}

\section{Sample Collection}

Ten test feeds were evaluated using the in situ and mobile nylon bag techniques. Silage samples were collected by field staff from silos located on farms of Mashad University, Iran. Silage samples were collected from at least 7 different areas within each silo. All 7 samples were thoroughly mixed, and a composite sample (50 g) was taken. The silage samples were immediately frozen at $-20^{\circ} \mathrm{C}$ until the onset of in situ determinations. After thawing silage, DM was determined by drying the whole sample in a forced air oven at $55^{\circ} \mathrm{C}$ until a constant weight was achieved. Forages samples were representative of the typical forage used by dairy farmers and were not identified by maturity or variety. Hay samples (alfalfa and barley) were collected from at least 7 separate haystacks. Cereal grain (corn and barley), WB, MM, FM, and SBM were collected from at least 10 different areas within a bin. All samples were dried in an oven at $100^{\circ} \mathrm{C}$ until a constant weight was achieved. All feedstuffs were then ground to pass through a 2-mm screen in a Wiley mill (model 4, Arthur H. Thomas Co., Philadelphia, PA) before incubation.

\section{Steers and Feeding}

Three steers were fitted with rumen fistulas, and 3 steers were fitted with T-shaped duodenal cannulas. All steers were fed a diet consisting of $2.5 \mathrm{~kg}$ of alfalfa, $5 \mathrm{~kg}$ of corn silage, $0.5 \mathrm{~kg}$ of barley hay, and $2.5 \mathrm{~kg}$ of a commercially prepared dairy concentrate (16\% protein, contained $48 \%$ BG, $16.8 \%$ CG, $8 \%$ SBM, $16.8 \%$ beet pulp, $8 \% \mathrm{WB}, 1.0 \%$ limestone, $0.3 \%$ urea, $0.4 \%$ salt, $0.2 \%$ vitamins and minerals supplement, and $0.1 \%$ dicalcium phosphate) on a DM basis (Table 1). The feed was fed in equal portions every $12 \mathrm{~h}$ to maintain a relatively stable rumen environment.

\section{In Situ Rumen Incubation of Feeds}

Nylon bags $(3 \times 6 \mathrm{~cm} ; 47-\mu \mathrm{m}$ pore size $)$ were filled with $1.2 \mathrm{~g}$ of dry, ground samples (De Boer et al., 1987) and were closed using glue. Each feed sample was incubated in 6 replicates ( 2 replicates for each steer) in the rumen for $12 \mathrm{~h}$. The incubation time was calculated assuming that residue time was equal to effective escape of CP from the rumen, calculated according to Ørskov and McDonald (1979), with a passage rate of 4.5\%/h (Van Straalen and Tamminga, 1990). Nylon bags were suspended in the rumen in a polyester mesh bag $(25 \times 40 \mathrm{~cm}$; $3 \mathrm{~mm}$ pore size $)$ and were removed from the rumen at the same time so that all bags could be washed simultaneously. The nylon bags were then removed from the mesh bag and placed in a conventional washing machine. Washings were repeated until the rinse water remained clear. Samples were then dried in an oven at $55^{\circ} \mathrm{C}$ until a constant weight was achieved before determination of DM disappearance. Replicates within steers were pooled and ground through a $0.5-\mathrm{mm}$ screen before $\mathrm{N}$ and $\mathrm{AA}$ analyses.

\section{In Situ Intestinal Incubation of Feeds}

Nutrient disappearance during passage through the intestine was determined using the mobile nylon bag technique (De Boer et al., 1987). Six replicate samples were incubated in the rumen of each steer for $12 \mathrm{~h}$ before being inserted into the intestine. Bags were inserted every 20 min into the duodenum through the Tshaped cannulas. Duodenal bags were collected from the feces and hand washed until the rinse water remained clear. Because of the limited amount of sample remaining, replicates within steers were pooled. Residual DM was conducted on the pooled residues from the mobile nylon bag after drying at $100^{\circ} \mathrm{C}$ for $24 \mathrm{~h}$.

\section{Chemical Analyses}

Determinations of $\mathrm{N}$ were conducted using the Kjeldahl method in an automated Kjelfoss apparatus (Foss Electric, Copenhagen, Denmark). Neutral detergent fiber and $\mathrm{ADF}$ were measured according to the method of Goering and Van Soest (1970). The AA analysis was performed after the samples were hydrolyzed in $6 \mathrm{M}$ hydrochloric acid for $24 \mathrm{~h}$ at $100^{\circ} \mathrm{C}$. Single AA analysis was carried out according to the procedures of Bidlinger et al. (1984), with the exception of Met which was determined after hydrolysis in formic acid for $24 \mathrm{~h}$ (Hagen et al., 1989).

\section{Calculations and Statistical Analyses}

The percent disappearance of the DM, CP, and AA at $12 \mathrm{~h}$ incubation in the rumen was calculated as the difference between the feed and the portion remaining after incubation in the rumen (Table 2). Disappearance 
Table 1. Nutrient composition, total AA, essential AA (EAA), nonessential AA (NEAA), and individual AA in feedstuffs (\% of DM). ${ }^{1}$

\begin{tabular}{|c|c|c|c|c|c|c|c|c|c|c|}
\hline \multirow[b]{2}{*}{ Variable } & \multicolumn{10}{|c|}{ Feedstuff $^{2}$} \\
\hline & MM & FM & CSM & SBM & CG & BG & $\mathrm{BH}$ & CS & $\mathrm{AH}$ & WB \\
\hline $\mathrm{DM}$ & 92.00 & 92.00 & 90.00 & 88.00 & 94.00 & 91.00 & 90.00 & 30.00 & 93.00 & 88.00 \\
\hline $\mathrm{CP}$ & 37.50 & 61.00 & 25.50 & 46.00 & 8.68 & 10.50 & 5.50 & 8.37 & 15.50 & 16.06 \\
\hline $\mathrm{N}$ & 6.00 & 9.76 & 4.08 & 7.36 & 1.39 & 1.68 & 0.88 & 1.34 & 2.48 & 2.57 \\
\hline NDF & $\ldots$ & $\ldots$ & 40.42 & 19.12 & 10.00 & 13.28 & 47.16 & 52.00 & 57.40 & 36.40 \\
\hline $\mathrm{ADF}$ & $\ldots$ & $\ldots$ & 27.00 & 86.00 & 3.70 & 4.60 & 29.74 & 35.00 & 46.18 & 11.38 \\
\hline Hemicellulose ${ }^{3}$ & & & 3.42 & 10.56 & 6.30 & 8.68 & 19.23 & 17.00 & 11.22 & 25.02 \\
\hline AA & 31.70 & 46.45 & 16.34 & 29.20 & 5.03 & 4.85 & 2.18 & 3.76 & 9.58 & 8.06 \\
\hline AA N & 5.07 & 7.43 & 2.61 & 4.67 & 0.80 & 0.77 & 0.35 & 0.60 & 1.53 & 1.89 \\
\hline EAA & 16.31 & 24.80 & 7.94 & 13.96 & 2.21 & 1.89 & 1.28 & 1.53 & 4.52 & 3.46 \\
\hline EAA N & 2.61 & 3.97 & 1.27 & 2.23 & 0.35 & 0.30 & 0.20 & 0.24 & 0.72 & 0.55 \\
\hline NEAA & 15.38 & 21.64 & 8.39 & 15.23 & 2.78 & 2.97 & 0.90 & 2.23 & 5.06 & 4.59 \\
\hline NEAA N & 2.46 & 3.46 & 1.34 & 2.43 & 0.44 & 0.47 & 0.14 & 0.35 & 0.81 & 0.73 \\
\hline \multicolumn{11}{|l|}{ EAA } \\
\hline Thr & 1.17 & 2.27 & 0.58 & 1.20 & 0.17 & 0.18 & 0.08 & 0.19 & 0.44 & 0.34 \\
\hline Val & 1.45 & 2.42 & 0.73 & 1.37 & 0.25 & 0.23 & 0.14 & 0.22 & 0.51 & 0.39 \\
\hline Ile & 0.84 & 1.95 & 0.48 & 1.23 & 0.13 & 0.13 & 0.06 & 0.11 & 0.36 & 0.21 \\
\hline Leu & 1.94 & 3.52 & 0.91 & 2.17 & 0.51 & 0.28 & 0.18 & 0.25 & 0.62 & 0.45 \\
\hline Tyr & 0.82 & 1.79 & 0.48 & 1.08 & 0.14 & 0.15 & 0.06 & 0.10 & 0.29 & 0.28 \\
\hline Phe & 1.15 & 2.10 & 0.92 & 1.53 & 0.25 & 0.25 & 0.17 & 0.17 & 0.48 & 0.36 \\
\hline His & 0.61 & 1.48 & 0.37 & 0.71 & 0.05 & 0.07 & 0.11 & 0.04 & 0.26 & 0.14 \\
\hline Lys & 1.49 & 3.66 & 0.67 & 1.67 & 0.11 & 0.14 & 0.10 & 0.14 & 0.48 & 0.27 \\
\hline Arg & 2.24 & 3.43 & 1.95 & 2.29 & 0.26 & 0.27 & 0.13 & 0.16 & 0.58 & 0.76 \\
\hline Met & 0.55 & 1.31 & 0.63 & 0.66 & 0.18 & 0.18 & 0.07 & 0.12 & 0.25 & 0.25 \\
\hline \multicolumn{11}{|l|}{ NEAA } \\
\hline Asp & 1.67 & 3.95 & 1.36 & 2.87 & 0.46 & 0.45 & 0.09 & 0.43 & 1.30 & 0.71 \\
\hline Ser & 1.34 & 1.98 & 0.82 & 1.65 & 0.26 & 0.23 & 0.08 & 0.24 & 0.52 & 0.45 \\
\hline Glu & 3.75 & 6.18 & 3.07 & 5.06 & 0.82 & 0.94 & 0.32 & 0.51 & 0.10 & 1.26 \\
\hline Pro & 2.62 & 2.59 & 1.13 & 2.41 & 0.69 & 0.71 & 0.13 & 0.43 & 1.04 & 0.86 \\
\hline Gly & 3.86 & 3.14 & 0.74 & 1.34 & 0.21 & 0.20 & 0.07 & 0.23 & 0.52 & 0.56 \\
\hline Ala & 2.27 & 3.37 & 0.63 & 1.21 & 0.33 & 0.19 & 0.11 & 0.31 & 0.48 & 0.42 \\
\hline Cys & 0.34 & 0.43 & 0.64 & 0.69 & 0.19 & 0.24 & 0.09 & 0.11 & 0.18 & 0.33 \\
\hline
\end{tabular}

${ }^{1}$ Three samples analyzed for each feed.

${ }^{2} \mathrm{MM}=$ Meat meal $; \mathrm{FM}$ = fish meal CSM = cottonseed meal SBM = soybean meal CG = corn grain; $\mathrm{BG}=$ barley grain; $\mathrm{BH}=$ barley hay; $\mathrm{CS}=$ corn silage; $\mathrm{AH}=$ alfalfa hay; $\mathrm{WB}=$ wheat bran.

${ }^{3}$ Hemicellulose calculated as NDF - ADF.

in the intestinal tract was calculated by the difference between the rumen residue after $12 \mathrm{~h}$ of incubation and the portion remaining in samples recovered from feces (Table 3). Differences between feedstuffs in rumen and intestine, and total tract disappearance of DM, CP, and AA were analyzed using the GLM procedure of SAS (SAS Institute, 1990), with Duncan's multiple range test used for the comparison of means. Feeds were the only sources of variation considered. Analytical variability was included in the error variance.

\section{RESULTS}

\section{Composition of Feedstuffs}

The chemical composition and total $\mathrm{N}$ composition of samples is shown in Table 1 . Total $\mathrm{N}$ content in the samples varied between $0.88 \% \mathrm{DM}$ for $\mathrm{BH}$ and $9.76 \%$ DM for FM. The lowest contribution of AA N to total $\mathrm{N}$ was observed for $\mathrm{BH}(39.7 \%)$ and the highest for $\mathrm{MM}$ (84.5\%). The percentage of essential amino acids (EAA) in AA varied between $34(\mathrm{BG})$ and $59(\mathrm{BH})$. Compared with the other feedstuffs, FM had a relatively high content of total $\mathrm{AA}$, and $\mathrm{BH}$ had a relatively low content of total AA. The Lys contents of CS and BH were low compared with values for the other feedstuffs.

\section{Ruminal Disappearance}

Values for disappearance of DM, CP, and AA after $12 \mathrm{~h}$ of rumen incubation are shown in Table 2 . There were differences between levels of disappearance for both DM and CP between feedstuffs $(P<0.05)$. The lowest level of DM disappearance was observed for CSM and MM $(31 \%)$, and the highest for BG $(64 \%)(P<0.05)$. The level of CP disappearance varied from $28 \%$ for CG to $65 \%$ for CSM. For BH and CS, the disappearance of AA was $(P<0.01)$ higher and lower than the other feedstuffs, respectively. The extent of disappearance of individual AA varied between feeds $(P<0.05)$. 
Table 2. Disappearance after $12 \mathrm{~h}$ rumen incubation of DM, CP, total AA, essential AA, nonessential AA, and individual AA in feedstuffs (\% of content in feed).

\begin{tabular}{|c|c|c|c|c|c|c|c|c|c|c|c|}
\hline \multirow[b]{2}{*}{ Variable $^{2}$} & \multicolumn{11}{|c|}{ Feedstuff $^{1}$} \\
\hline & MM & FM & CSM & SBM & CG & BG & $\mathrm{BH}$ & CS & $\mathrm{AH}$ & WB & SEM \\
\hline DM & $31.0^{f}$ & $34.0^{\mathrm{f}}$ & $31.0^{f}$ & $50.0^{\mathrm{c}}$ & $35.0^{\mathrm{ef}}$ & $64.0^{\mathrm{a}}$ & $52.0^{\mathrm{bc}}$ & $38.0^{\mathrm{de}}$ & $41.0^{\mathrm{d}}$ & $55.0^{\mathrm{b}}$ & 1.6 \\
\hline $\mathrm{CP}$ & $32.0^{\text {de }}$ & $32.0^{\mathrm{d}}$ & $65.0^{\mathrm{a}}$ & $33.0^{\text {de }}$ & $28.0^{\mathrm{f}}$ & $58.0^{\mathrm{b}}$ & $59.0^{\mathrm{b}}$ & $29.0^{\mathrm{ef}}$ & $51.0^{c}$ & $60.0^{\mathrm{b}}$ & 1.5 \\
\hline $\mathrm{AA}$ & $44.0^{\mathrm{bcd}}$ & $42.0^{\mathrm{d}}$ & $29.0^{\text {ef }}$ & $20.0^{\mathrm{f}}$ & $54.0^{\mathrm{b}}$ & $34.0^{\text {de }}$ & $68.0^{\mathrm{a}}$ & $19.0^{\mathrm{f}}$ & $51.0^{\mathrm{bc}}$ & $66.0^{\mathrm{a}}$ & 4.6 \\
\hline EAA & $55.0^{\mathrm{bc}}$ & $49.0^{\mathrm{c}}$ & $29.0^{\text {de }}$ & $18.0^{\text {ef }}$ & $57.0^{\mathrm{bc}}$ & $28.0^{\text {de }}$ & $74.0^{\mathrm{a}}$ & $15.0^{\mathrm{f}}$ & $36.0^{\mathrm{d}}$ & $62.0^{\mathrm{b}}$ & 4.7 \\
\hline NEAA & $30.0^{\text {cd }}$ & $35.0^{\mathrm{c}}$ & $28.0^{\text {cd }}$ & $21.0^{\mathrm{d}}$ & $51.0^{\mathrm{b}}$ & $36.0^{c}$ & $61.0^{\mathrm{ab}}$ & $25.0^{\text {cd }}$ & $63.0^{\mathrm{ab}}$ & $71.0^{\mathrm{a}}$ & 5.0 \\
\hline \multicolumn{12}{|l|}{ EAA } \\
\hline Thr & $24.0^{\mathrm{d}}$ & $39.0^{\mathrm{c}}$ & $19.0^{\mathrm{d}}$ & $17.0^{\mathrm{d}}$ & $53.0^{\mathrm{ab}}$ & $48.0^{\mathrm{abc}}$ & $60.0^{\mathrm{a}}$ & $24.0^{\mathrm{d}}$ & $420^{\mathrm{bc}}$ & $56.0^{\mathrm{a}}$ & 5.1 \\
\hline Val & $27.0^{\mathrm{d}}$ & $36.0^{\mathrm{c}}$ & $30.0^{\mathrm{d}}$ & $40.0^{\mathrm{bc}}$ & $58.0^{\mathrm{a}}$ & $50.0^{\mathrm{ab}}$ & $60.0^{\mathrm{a}}$ & $27.0^{\mathrm{d}}$ & $41.0^{\mathrm{bc}}$ & $60.0^{\mathrm{a}}$ & 4.7 \\
\hline Ile & $26.0^{\text {de }}$ & $35.0^{\text {cd }}$ & $21.0^{\mathrm{e}}$ & $15.0^{\mathrm{ef}}$ & $52.0^{\mathrm{ab}}$ & $43.0^{\mathrm{bc}}$ & $42.0^{\mathrm{bc}}$ & $8.50^{f}$ & $41.0^{\mathrm{c}}$ & $5.50^{\mathrm{a}}$ & 4.8 \\
\hline Leu & $31.0^{\mathrm{de}}$ & $38.0^{\text {cd }}$ & $24.0^{\mathrm{e}}$ & $19.0^{\mathrm{e}}$ & $58.0^{\mathrm{ab}}$ & $48.0^{\mathrm{bc}}$ & $65.0^{\mathrm{a}}$ & $23.0^{\mathrm{e}}$ & $4.20^{\mathrm{d}}$ & $6.10^{\mathrm{a}}$ & 4.7 \\
\hline Tyr & $27.0^{\mathrm{cd}}$ & $38.0^{\mathrm{bc}}$ & $34.0^{\mathrm{bc}}$ & $17.0^{\mathrm{d}}$ & $48.0^{\mathrm{b}}$ & $45.0^{\mathrm{b}}$ & $67.0^{\mathrm{a}}$ & $40.0^{\mathrm{bc}}$ & $47.0^{\mathrm{b}}$ & $72.0^{\mathrm{a}}$ & 6.0 \\
\hline Phe & $25.0^{\text {de }}$ & $36.0^{\text {de }}$ & $23.0^{\mathrm{f}}$ & $18.0^{\mathrm{f}}$ & $50.0^{\mathrm{bc}}$ & $44.0^{\mathrm{cd}}$ & $64.0^{\mathrm{a}}$ & $12.0^{\mathrm{f}}$ & $40.0^{\mathrm{cd}}$ & $62.0^{\mathrm{ab}}$ & 5.4 \\
\hline His & $38.0^{\mathrm{c}}$ & $51.0^{\mathrm{b}}$ & $13.0^{\mathrm{d}}$ & $17.0^{\mathrm{d}}$ & $56.0^{\mathrm{b}}$ & $56.0^{\mathrm{b}}$ & $52.0^{\mathrm{b}}$ & $29.0^{\mathrm{c}}$ & $69.0^{\mathrm{a}}$ & $70.0^{\mathrm{a}}$ & 4.1 \\
\hline Lys & $40.0^{\mathrm{c}}$ & $44.0^{\mathrm{c}}$ & $39.0^{\mathrm{c}}$ & $24.0^{\mathrm{d}}$ & $62.0^{\mathrm{b}}$ & $74.0^{\mathrm{a}}$ & $64.0^{\mathrm{b}}$ & $13.0^{\mathrm{e}}$ & $63.0^{\mathrm{b}}$ & $60.0^{\mathrm{b}}$ & 3.7 \\
\hline Arg & $40.0^{\text {ef }}$ & $46.0^{\mathrm{de}}$ & $36.0^{f}$ & $23.0^{\mathrm{g}}$ & $61.0^{\mathrm{bc}}$ & $51.0^{\text {cd }}$ & $73.0^{\mathrm{a}}$ & $6.0^{\mathrm{h}}$ & $56.0^{\text {cd }}$ & $71.0^{\mathrm{ab}}$ & 4.4 \\
\hline Met & $33.0^{\mathrm{bc}}$ & $27.0^{\text {cd }}$ & $33.0^{\mathrm{bc}}$ & $18.0^{\mathrm{d}}$ & $41.0^{\mathrm{b}}$ & $38.0^{\mathrm{b}}$ & $75.0^{\mathrm{a}}$ & $25.0^{\text {cd }}$ & $25.0^{\mathrm{cd}}$ & $70.0^{\mathrm{a}}$ & 4.1 \\
\hline \multicolumn{12}{|l|}{ NEAA } \\
\hline Asp & $54.0^{\mathrm{bc}}$ & $44.0^{\text {cd }}$ & $35.0^{\mathrm{de}}$ & $16.0^{\mathrm{f}}$ & $53.0^{\mathrm{bc}}$ & $52.0^{\mathrm{bc}}$ & $30.0^{\mathrm{e}}$ & $38.0^{\mathrm{de}}$ & $63.0^{\mathrm{ab}}$ & $73.0^{\mathrm{a}}$ & 4.3 \\
\hline Ser & $32.0^{\mathrm{de}}$ & $37.0^{\mathrm{cd}}$ & $23.0^{\text {ef }}$ & $18.0^{\mathrm{f}}$ & $53.0^{\mathrm{ab}}$ & $48.0^{\mathrm{bc}}$ & $53.0^{\mathrm{ab}}$ & $25.0^{\text {def }}$ & $47.0^{\mathrm{bc}}$ & $61.0^{\mathrm{a}}$ & 5.2 \\
\hline Glu & $49.0^{c}$ & $44.0^{\mathrm{c}}$ & $49.0^{\mathrm{c}}$ & $22.0^{\mathrm{e}}$ & $63.0^{\mathrm{b}}$ & $53.0^{\mathrm{bc}}$ & $47.0^{\mathrm{c}}$ & $33.0^{\mathrm{d}}$ & $53.0^{\mathrm{c}}$ & $80.0^{\mathrm{a}}$ & 4.3 \\
\hline Pro & $34.0^{\text {de }}$ & $31.0^{\mathrm{e}}$ & $18.0^{f}$ & $26.0^{\text {ef }}$ & $52.0^{\mathrm{c}}$ & $55.0^{\mathrm{abc}}$ & $44.0^{\mathrm{cd}}$ & $34.0^{\mathrm{de}}$ & $56.0^{\mathrm{ab}}$ & $66.0^{\mathrm{a}}$ & 4.5 \\
\hline Gly & $41.0^{\mathrm{d}}$ & $48.0^{\mathrm{bcd}}$ & $23.0^{\mathrm{e}}$ & $21.0^{\mathrm{e}}$ & $52.0^{\mathrm{bc}}$ & $58.0^{\mathrm{ab}}$ & $45.0^{\mathrm{cd}}$ & $28.0^{\mathrm{e}}$ & $41.0^{\mathrm{d}}$ & $66.0^{\mathrm{a}}$ & 4.2 \\
\hline Ala & $34.0^{\mathrm{de}}$ & $47.0^{\mathrm{bc}}$ & $25.0^{\mathrm{ef}}$ & $18.0^{\mathrm{f}}$ & $55.0^{\mathrm{ab}}$ & $47.0^{\mathrm{bc}}$ & $65.0^{\mathrm{a}}$ & $39.0^{\text {cd }}$ & $42.0^{\mathrm{cd}}$ & $59.0^{\mathrm{a}}$ & 4.6 \\
\hline Cys & $19.0^{\mathrm{e}}$ & $36.0^{\mathrm{d}}$ & $35.0^{\mathrm{d}}$ & $25.0^{\mathrm{e}}$ & $53.0^{\mathrm{bc}}$ & $60.0^{\mathrm{b}}$ & $48.0^{\mathrm{c}}$ & $35.0^{\mathrm{d}}$ & $54.0^{\mathrm{bc}}$ & $79.0^{\mathrm{a}}$ & 3.7 \\
\hline
\end{tabular}

a,b,c,d,e,f Means within a row with different subscripts differ $(P<0.05)$.

${ }^{1} \mathrm{MM}=$ Meat meal; $\mathrm{FM}$ = fish meal $; \mathrm{CSM}=$ cottonseed meal $; \mathrm{SBM}=$ soybean meal $; \mathrm{CG}=$ corn grain; $\mathrm{BG}=$ barley grain; $\mathrm{BH}=$ barley hay; $\mathrm{CS}=$ corn silage; $\mathrm{AH}=$ alfalfa hay; $\mathrm{WB}=$ wheat bran.

${ }^{2} \mathrm{EAA}=$ Essential AA; NEAA = nonessential AA.

\section{Intestinal Disappearance}

The disappearances of DM, CP, and AA expressed as a percentage of the rumen residue, differed $(P<0.05)$ between feedstuffs (Table 3 ). Dry matter disappearance varied from $17 \%$ for $\mathrm{BH}$ to $89 \%$ for $\mathrm{FM}$, whereas $\mathrm{CP}$ disappearance ranged from $30 \%$ for WB to $93 \%$ for FM. Disappearance of total AA varied from $26 \%$ for $\mathrm{BH}$ to $91 \%$ for FM. For FM, the disappearances of total AA, EAA, and nonessential amino acids (NEAA) were higher than other feedstuffs $(P<0.05)$, in contrast to disappearance of total AA from $\mathrm{BH}$, which was lower $(P<0.05)$ than the other feedstuffs. For FM, the level of disappearance of many AA including Thr, Val, Ile, Leu, Tyr, Phe, His, Arg, Asp, Ser, Glu, Pro, Gly, and Ala were higher $(P<0.05)$ than for the other feedstuffs, in contrast to $\mathrm{BH}$, which had lowered $(P<0.05)$ disappearance of these AA. The extent of Lys disappearance varied from $40 \%$ in BG to $89 \%$ in CSM. For BG, the disappearance of Met as a percentage of initial Met was higher $(P<0.01)$ than that of the other feedstuffs.

\section{Total Tract Disappearance}

Values for disappearance of DM, CP, and AA in total tract for each feedstuff are given in Table 4 . There were differences between levels of disappearance for both $\mathrm{DM}$ and CP between feedstuffs $(P<0.05)$. The lowest and highest extent of DM disappearance was observed in CSM (47\%) and FM (95\%), respectively. For CP, the level of disappearance varied from $68 \%$ for $\mathrm{BH}$ to $95 \%$ for FM. In CS, the disappearance of AA was lower ( $P$ $<0.01)$ than that of the other feedstuffs, whereas disappearance of total AA from FM was higher $(P<0.01)$ than from the other feedstuffs. The disappearance of EAA varied from $70 \%$ for CS to $95 \%$ for FM. In addition, disappearance of NEAA in $\mathrm{BH}$ and CS were lower $(P$ $<0.05)$ than in the other feedstuffs, whereas values for FM were higher than the other feedstuffs. Moreover, the level of disappearance of Val, Ile, His, Lys, Asp, Ser, Glu, Pro, Gly, and Cys in FM were higher than other feedstuffs $(P<0.05)$, in contrast to $\mathrm{BH}$, which had a lower $(P<0.05)$ disappearance of these AA than the other feedstuffs. For CS, the disappearance of Thr, Leu, Tyr, Phe, and Arg were lower compared with FM, which had a higher disappearance of these AA than the other feedstuffs $(P<0.05)$. For AH, the disappearance of Met was lower $(P<0.01)$ than the other feedstuffs, whereas the disappearance of Met was higher for $\mathrm{BH}$ $(P<0.01)$ than for the other feedstuffs. In addition, MM and FM had the lowest and highest $(P<0.01)$ extent 
Table 3. Intestinal disappearance of DM, CP, total AA, essential AA, nonessential AA, and individual AA of feedstuffs (\% of 12-h rumen residue).

\begin{tabular}{|c|c|c|c|c|c|c|c|c|c|c|c|}
\hline \multirow[b]{2}{*}{ Variable $^{2}$} & \multicolumn{11}{|c|}{ Feedstuff $^{1}$} \\
\hline & MM & FM & CSM & SBM & $\mathrm{CG}$ & BG & $\mathrm{BH}$ & $\mathrm{CS}$ & $\mathrm{AH}$ & WB & SEI \\
\hline DM & $50.0^{\mathrm{bc}}$ & $89.0^{\mathrm{a}}$ & $24.0^{\mathrm{ef}}$ & $41.0^{\mathrm{cd}}$ & $56.0^{\mathrm{b}}$ & $41.0^{\mathrm{cd}}$ & $17.0^{\mathrm{f}}$ & $46.0^{\mathrm{bcd}}$ & $19.0^{\mathrm{f}}$ & $34.0^{\mathrm{de}}$ & 5.6 \\
\hline CP & $66.0^{\mathrm{e}}$ & $93.0^{\mathrm{a}}$ & $80.0^{\mathrm{bcd}}$ & $86.0^{\mathrm{abc}}$ & $89.0^{\mathrm{a}}$ & $79.0^{\mathrm{cd}}$ & $36.0^{\mathrm{g}}$ & $89.0^{\mathrm{ab}}$ & $73.0^{\text {de }}$ & $30.0^{\mathrm{g}}$ & 3.8 \\
\hline $\mathrm{AA}$ & $58.0^{\mathrm{d}}$ & $91.0^{\mathrm{a}}$ & $78.0^{\mathrm{ab}}$ & $84.0^{\mathrm{ab}}$ & $73.0^{\mathrm{bc}}$ & $82.0^{\mathrm{ab}}$ & $26.0^{\mathrm{f}}$ & $62.0^{\text {cd }}$ & $50.0^{\text {de }}$ & $38.0^{\text {ef }}$ & 4.5 \\
\hline EAA & $9.0^{\mathrm{e}}$ & $90.0^{\mathrm{a}}$ & $81.0^{\mathrm{abc}}$ & $84.0^{\mathrm{ab}}$ & $70.0^{\mathrm{cd}}$ & $83.0^{\mathrm{abc}}$ & $28.0^{\mathrm{f}}$ & $66.0^{\mathrm{d}}$ & $83.0^{\mathrm{abc}}$ & $71.0^{\text {bcd }}$ & 5.8 \\
\hline NEAA & $76.0^{\mathrm{b}}$ & $94.0^{\mathrm{a}}$ & $77.0^{\mathrm{b}}$ & $83.0^{\mathrm{ab}}$ & $76.0^{\mathrm{b}}$ & $82.0^{\mathrm{ab}}$ & $22.0^{\mathrm{d}}$ & $59.0^{c}$ & $22.0^{\mathrm{d}}$ & $61.0^{\mathrm{c}}$ & 5.3 \\
\hline \multicolumn{12}{|l|}{ EAA } \\
\hline Thr & $73.0^{\mathrm{b}}$ & $91.0^{\mathrm{a}}$ & $76.0^{\mathrm{b}}$ & $90.0^{\mathrm{a}}$ & $60.0^{\mathrm{c}}$ & $46.0^{\mathrm{d}}$ & $29.0^{\mathrm{e}}$ & $56.0^{\mathrm{cd}}$ & $54.0^{\mathrm{cd}}$ & $66.0^{\mathrm{bc}}$ & 5.5 \\
\hline Val & $71.0^{\text {cde }}$ & $90.0^{\mathrm{a}}$ & $77.0^{\mathrm{bc}}$ & $84.0^{\mathrm{ab}}$ & $70.0^{\text {cde }}$ & $74.0^{\mathrm{c}}$ & $32.0^{f}$ & $62.0^{\mathrm{de}}$ & $61.0^{\mathrm{e}}$ & $71.0^{\text {cd }}$ & 3.2 \\
\hline Ile & $70.0^{\text {cd }}$ & $91.0^{\mathrm{a}}$ & $77.0^{\mathrm{bc}}$ & $84.0^{\mathrm{ab}}$ & $68.0^{\text {cd }}$ & $73.0^{\mathrm{cd}}$ & $35.0^{\mathrm{e}}$ & $65.0^{\mathrm{d}}$ & $66.0^{\mathrm{d}}$ & $67.0^{\mathrm{d}}$ & 4.0 \\
\hline Leu & $70.0^{\text {cd }}$ & $92.0^{\mathrm{a}}$ & $79.0^{\mathrm{b}}$ & $83.0^{\mathrm{b}}$ & $82.0^{\mathrm{b}}$ & $77.0^{\mathrm{bc}}$ & $38.0^{\mathrm{e}}$ & $69.0^{\mathrm{d}}$ & $68.0^{\mathrm{d}}$ & $68.0^{\mathrm{d}}$ & 4.0 \\
\hline Tyr & $77.0^{\mathrm{bc}}$ & $89.0^{\mathrm{a}}$ & $83.0^{\mathrm{ab}}$ & $88.0^{\mathrm{a}}$ & $68.0^{\text {cd }}$ & $79.0^{\mathrm{ab}}$ & $23.0^{f}$ & $54.0^{\mathrm{e}}$ & $54.0^{\mathrm{e}}$ & $62.0^{\text {de }}$ & 3.3 \\
\hline Phe & $69.0^{\text {cd }}$ & $92.0^{\mathrm{a}}$ & $85.0^{\mathrm{ab}}$ & $84.0^{\mathrm{ab}}$ & $74.0^{\mathrm{bc}}$ & $75.0^{\mathrm{bc}}$ & $22.0^{\mathrm{f}}$ & $55.0^{\mathrm{e}}$ & $56.0^{\mathrm{e}}$ & $66.0^{\text {de }}$ & 4.4 \\
\hline His & $74.0^{\text {cd }}$ & $95.0^{\mathrm{a}}$ & $82.0^{\mathrm{b}}$ & $85.0^{\mathrm{ab}}$ & $60.0^{\mathrm{e}}$ & $78.0^{\mathrm{bc}}$ & $33.0^{f}$ & $63.0^{\mathrm{de}}$ & $59.0^{\mathrm{e}}$ & $80.0^{\mathrm{bc}}$ & 4.1 \\
\hline Lys & $69.0^{\text {cd }}$ & $89.0^{\mathrm{a}}$ & $83.0^{\mathrm{ab}}$ & $87.0^{\mathrm{ab}}$ & $56.0^{\mathrm{e}}$ & $40.0^{\mathrm{f}}$ & $50.0^{\mathrm{e}}$ & $81.0^{\mathrm{bc}}$ & $70.0^{\mathrm{d}}$ & $61.0^{\text {ef }}$ & 3.9 \\
\hline Arg & $59.0^{\mathrm{d}}$ & $91.0^{\mathrm{a}}$ & $88.0^{\mathrm{a}}$ & $85.0^{\mathrm{ab}}$ & $73.0^{\mathrm{c}}$ & $74.0^{\mathrm{c}}$ & $43.0^{\mathrm{e}}$ & $57.0^{\mathrm{d}}$ & $63.0^{\mathrm{d}}$ & $79.0^{\mathrm{bc}}$ & 3.3 \\
\hline Met & $75.0^{\text {de }}$ & $90.0^{\mathrm{ab}}$ & $88.0^{\mathrm{ab}}$ & $90.0^{\mathrm{ab}}$ & $86.0^{\mathrm{abc}}$ & $93.0^{\mathrm{a}}$ & $83.0^{\mathrm{bcd}}$ & $80.0^{\text {cde }}$ & $47.0^{\mathrm{f}}$ & $73.0^{\mathrm{e}}$ & 3.7 \\
\hline \multicolumn{12}{|l|}{ NEAA } \\
\hline Asp & $2.0^{\mathrm{d}}$ & $92.0^{\mathrm{a}}$ & $65.0^{\mathrm{cd}}$ & $83.0^{\mathrm{ab}}$ & $74.0^{\mathrm{bc}}$ & $62.0^{\mathrm{d}}$ & $16.0^{\mathrm{g}}$ & $38.0^{\mathrm{e}}$ & $22.0^{\mathrm{fg}}$ & $32.0^{\mathrm{ef}}$ & 3.2 \\
\hline Ser & $69.0^{\mathrm{b}}$ & $91.0^{\mathrm{a}}$ & $73.0^{\mathrm{b}}$ & $83.0^{\mathrm{a}}$ & $67.0^{\mathrm{b}}$ & $67.0^{\mathrm{b}}$ & $60.0^{\mathrm{d}}$ & $50.0^{\mathrm{c}}$ & $40.0^{\mathrm{c}}$ & $63.0^{\mathrm{b}}$ & 4.4 \\
\hline Glu & $65.0^{c}$ & $92.0^{\mathrm{a}}$ & $81.0^{\mathrm{b}}$ & $83.0^{\mathrm{ab}}$ & $79.0^{\mathrm{b}}$ & $82.0^{\mathrm{b}}$ & $31.0^{\mathrm{f}}$ & $56.0^{\mathrm{cd}}$ & $42.0^{\mathrm{e}}$ & $50.0^{\text {de }}$ & 4.2 \\
\hline Pro & $57.0^{\mathrm{d}}$ & $92.0^{\mathrm{a}}$ & $80.0^{c}$ & $90.0^{\mathrm{ab}}$ & $77.0^{c}$ & $82.0^{\text {bc }}$ & $28.0^{\mathrm{e}}$ & $56.0^{\mathrm{d}}$ & $56.0^{\mathrm{d}}$ & $75.0^{\mathrm{c}}$ & 3.9 \\
\hline Gly & $49.0^{\mathrm{ef}}$ & $89.0^{\mathrm{a}}$ & $76.0^{\mathrm{bc}}$ & $82.0^{\mathrm{ab}}$ & $62.0^{\mathrm{de}}$ & $55.0^{\text {def }}$ & $14.0^{\mathrm{g}}$ & $48.0^{\mathrm{f}}$ & $49.0^{\mathrm{ef}}$ & $63.0^{\mathrm{cd}}$ & 5.3 \\
\hline Ala & $62.0^{\mathrm{c}}$ & $91.0^{\mathrm{a}}$ & $69.0^{\text {bc }}$ & $93.0^{\mathrm{a}}$ & $75.0^{\mathrm{b}}$ & $64.0^{\mathrm{c}}$ & $28.0^{\mathrm{e}}$ & $75.0^{\mathrm{b}}$ & $50.0^{\mathrm{d}}$ & $63.0^{\mathrm{c}}$ & 4.1 \\
\hline Cys & $67.0^{\mathrm{c}}$ & $88.0^{\mathrm{a}}$ & $85.0^{\mathrm{a}}$ & $85.0^{\mathrm{a}}$ & $80.0^{\mathrm{ab}}$ & $80.0^{\mathrm{ab}}$ & $20.0^{\mathrm{e}}$ & $49.0^{\mathrm{d}}$ & $62.0^{\mathrm{c}}$ & $70.0^{\mathrm{bc}}$ & 4.3 \\
\hline
\end{tabular}

a,b,c,d,e,f Means within a row with different subscripts differ $(P<0.05)$.

${ }^{1} \mathrm{MM}=$ Meat meal $; \mathrm{FM}=$ fish meal CSM = cottonseed meal SBM = soybean meal CG = corn grain; $\mathrm{BG}=$ barley grain; $\mathrm{BH}=$ barley hay; $\mathrm{CS}=$ corn silage; $\mathrm{AH}=$ alfalfa hay; $\mathrm{WB}=$ wheat bran

${ }^{2} \mathrm{EAA}=$ Essential AA; NEAA = nonessential AA.

of disappearance of Ala among the feedstuffs, respectively.

\section{DISCUSSION}

\section{Feedstuff Composition}

The DM, CP, and AA profiles of feedstuffs observed in this experiment differed from that published by NRC (2001). The content of AA nitrogen in total N for FM was lower than previously cited (Harstad and Prestløkken, 2001). Furthermore, there were differences in EAA $\mathrm{N}$ :NEAA $\mathrm{N}$ ratio and profiles of individual AA between tabulated values and values measured in the current experiment. The total AA N and EAA N in CS differed from those observed by Van Straalen et al. (1997; 6.9 and $6.6 \%$ of DM, respectively). Because it was not possible to fully identify the feedstuff samples as to maturity, variety, processing, and fertilization, these factors will not be subject to discussion.

\section{Ruminal Degradability}

For most feedstuffs, the residual $\mathrm{N}$ after a 12 -h rumen incubation was lower than the effectively fermented fraction calculated from degradation characteristics in the rumen (Chiou et al., 1995) using an assumed passage rate of $5 \%$ per h $[\mathrm{AH}, 70 \%$; CS, $77.5 \%$; FM, 38.5\%; SBM, 7\%; MM, 54\%; WB, $82.6 \%$ ]. The pooling of the mobile bag residue per feed and steer before $\mathrm{N}$ analysis was modeled on the work of Van Straalen et al. (1993). Mobile bag contents in the present study were not corrected for microbial contamination because Kohn and Allen (1992) reported limited microbial contamination for mobile nylon bag studies. However, some reports indicate microbial contamination of rumen residues can have a large effect on the amino acid profile of the residues (Rooke, 1985).

In the present study, all bags were thoroughly washed before DM, CP, and AA analyses. Washing has been reported to remove essentially all endogenous and bacterial contamination. According to the literature, Tyr in SBM is relatively undegradable (Varvikko et al., 1983), although we were unable to confirm this observation in our experiment. Degradation in individual AA (19\%) in CS was different from that reported by Van Straalen et al. $(71 \%$; 1997). The values for estimated microbial contamination reported in Van Straalen et al. (1997) were 5 and $36 \%$ of total AA N for SBM and $\mathrm{CS}$, respectively. In addition to differences in solubility and microbial contamination, changes in the AA profile 
Table 4. Disappearance in the total tract of DM, CP, total AA, essential AA, nonessential AA, and individual $\mathrm{AA}$ in feedstuffs (\% of DM).

\begin{tabular}{|c|c|c|c|c|c|c|c|c|c|c|c|}
\hline \multirow[b]{2}{*}{ Variable $^{\mathrm{s}}$} & \multicolumn{11}{|c|}{ Feedstuff $^{1}$} \\
\hline & MM & FM & CSM & SBM & CG & BG & $\mathrm{BH}$ & $\mathrm{CS}$ & $\mathrm{AH}$ & WB & SEM \\
\hline DM & $66.0^{\mathrm{d}}$ & $93.0^{\mathrm{a}}$ & $47.0^{\mathrm{f}}$ & $89.0^{\mathrm{ab}}$ & $91.0^{\mathrm{a}}$ & $84.0^{\mathrm{bc}}$ & $70.0^{\mathrm{d}}$ & $81.0^{\mathrm{c}}$ & $54.0^{\mathrm{e}}$ & $71.0^{\mathrm{d}}$ & 3.0 \\
\hline CP & $77.0^{\mathrm{d}}$ & $95.0^{\mathrm{a}}$ & $87.0^{\mathrm{c}}$ & $89.0^{\mathrm{bc}}$ & $94.0^{\mathrm{ab}}$ & $91.0^{\mathrm{abc}}$ & $68.0^{\mathrm{e}}$ & $73.0^{\mathrm{de}}$ & $87.0^{\mathrm{c}}$ & $90.0^{\mathrm{abc}}$ & 2.1 \\
\hline $\mathrm{AA}$ & $77.0^{\mathrm{c}}$ & $96.0^{\mathrm{a}}$ & $84.0^{\mathrm{b}}$ & $87.0^{\mathrm{b}}$ & $88.0^{\mathrm{b}}$ & $85.0^{\mathrm{b}}$ & $75.0^{\mathrm{c}}$ & $69.0^{\mathrm{d}}$ & $76.0^{c}$ & $88.0^{\mathrm{b}}$ & 2.5 \\
\hline EAA & $78.0^{\mathrm{d}}$ & $95.0^{\mathrm{a}}$ & $86.0^{\mathrm{bc}}$ & $87.0^{\mathrm{bc}}$ & $87.0^{\mathrm{bc}}$ & $88.0^{\mathrm{bc}}$ & $81.0^{\mathrm{cd}}$ & $70.0^{\mathrm{e}}$ & $81.0^{\text {cd }}$ & $89.0^{\mathrm{ab}}$ & 2.7 \\
\hline NEAA & $76.0^{\mathrm{c}}$ & $95.0^{\mathrm{a}}$ & $84.0^{\mathrm{b}}$ & $87.0^{\mathrm{b}}$ & $88.0^{\mathrm{b}}$ & $89.0^{\mathrm{b}}$ & $70.0^{c}$ & $70.0^{\mathrm{c}}$ & $71.0^{\mathrm{c}}$ & $88.0^{\mathrm{b}}$ & 2.8 \\
\hline \multicolumn{12}{|l|}{ EAA } \\
\hline Thr & $80.0^{\text {bcd }}$ & $95.0^{\mathrm{a}}$ & $81.0^{\mathrm{bc}}$ & $86.0^{\mathrm{b}}$ & $76.0^{\text {cde }}$ & $80.0^{\mathrm{bcd}}$ & $71.0^{\mathrm{ef}}$ & $66.0^{\mathrm{f}}$ & $73.0^{\mathrm{de}}$ & $86.0^{\mathrm{b}}$ & 3.0 \\
\hline Val & $9.0^{\mathrm{cd}}$ & $94.0^{\mathrm{a}}$ & $82.0^{\mathrm{bc}}$ & $87.0^{\mathrm{b}}$ & $87.0^{\mathrm{b}}$ & $86.0^{\mathrm{b}}$ & $68.0^{\mathrm{e}}$ & $73.0^{\text {de }}$ & $78.0^{\text {cd }}$ & $88.0^{\mathrm{ab}}$ & 2.6 \\
\hline Ile & $79.0^{\mathrm{d}}$ & $94.0^{\mathrm{a}}$ & $83.0^{\mathrm{bcd}}$ & $87.0^{\mathrm{b}}$ & $84.0^{\mathrm{bcd}}$ & $82.0^{\mathrm{d}}$ & $63.0^{\mathrm{e}}$ & $67.0^{\mathrm{e}}$ & $80.0^{\text {cd }}$ & $86.0^{\mathrm{bc}}$ & 2.3 \\
\hline Leu & $1.0^{\mathrm{de}}$ & $95.0^{\mathrm{a}}$ & $84.0^{\mathrm{cd}}$ & $92.0^{\mathrm{ab}}$ & $92.0^{\mathrm{ab}}$ & $88.0^{c}$ & $79.0^{\mathrm{ef}}$ & $75.0^{\mathrm{f}}$ & $81.0^{\mathrm{de}}$ & $88.0^{\mathrm{bc}}$ & 1.7 \\
\hline Tyr & $2.0^{\mathrm{b}}$ & $93.0^{\mathrm{a}}$ & $87.0^{\mathrm{ab}}$ & $87.0^{\mathrm{ab}}$ & $82.0^{\mathrm{b}}$ & $88.0^{\mathrm{ab}}$ & $75.0^{\mathrm{c}}$ & $73.0^{\mathrm{c}}$ & $75.0^{\mathrm{c}}$ & $89.0^{\mathrm{a}}$ & 2.6 \\
\hline Phe & $3.0^{c}$ & $93.0^{\mathrm{a}}$ & $87.0^{\mathrm{ab}}$ & $92.0^{\mathrm{a}}$ & $87.0^{\mathrm{ab}}$ & $84.0^{\mathrm{b}}$ & $75.0^{\mathrm{c}}$ & $62.0^{\mathrm{d}}$ & $74.0^{\mathrm{c}}$ & $85.0^{\mathrm{b}}$ & 2.4 \\
\hline His & $81.0^{\mathrm{d}}$ & $96.0^{\mathrm{a}}$ & $86.0^{\text {bcd }}$ & $87.0^{\mathrm{bc}}$ & $82.0^{\mathrm{cd}}$ & $89.0^{\mathrm{b}}$ & $67.0^{\mathrm{f}}$ & $74.0^{\mathrm{e}}$ & $87.0^{\mathrm{bc}}$ & $90.0^{\mathrm{b}}$ & 2.2 \\
\hline Lys & $83.0^{c}$ & $97.0^{\mathrm{a}}$ & $89.0^{\mathrm{b}}$ & $90.0^{\mathrm{b}}$ & $83.0^{c}$ & $89.0^{\mathrm{b}}$ & $82.0^{c}$ & $83.0^{c}$ & $89.0^{\mathrm{b}}$ & $92.0^{\mathrm{ab}}$ & 2.2 \\
\hline Arg & $5.0^{f}$ & $95.0^{\mathrm{a}}$ & $93.0^{\mathrm{ab}}$ & $89.0^{\text {bcd }}$ & $89.0^{\mathrm{bc}}$ & $86.0^{\text {cde }}$ & $84.0^{\mathrm{de}}$ & $60.0^{\mathrm{g}}$ & $84.0^{\mathrm{e}}$ & $94.0^{\mathrm{a}}$ & 2.0 \\
\hline Met & $83.0^{\mathrm{c}}$ & $92.0^{\mathrm{ab}}$ & $92.0^{\mathrm{ab}}$ & $87.0^{c}$ & $92.0^{\mathrm{ab}}$ & $94.0^{\mathrm{a}}$ & $95.0^{\mathrm{a}}$ & $85.0^{\mathrm{c}}$ & $59.0^{\mathrm{d}}$ & $91.0^{\mathrm{ab}}$ & 2.2 \\
\hline \multicolumn{12}{|l|}{ NEAA } \\
\hline Asp & $3.0^{\mathrm{bc}}$ & $95.0^{\mathrm{a}}$ & $81.0^{\mathrm{bc}}$ & $86.0^{\mathrm{bc}}$ & $87.0^{\mathrm{b}}$ & $80.0^{\mathrm{c}}$ & $42.0^{\mathrm{f}}$ & $61.0^{\mathrm{e}}$ & $71.0^{\mathrm{d}}$ & $80.0^{\mathrm{e}}$ & 2.9 \\
\hline Ser & $80.0^{\mathrm{bc}}$ & $94.0^{\mathrm{a}}$ & $79.0^{\mathrm{c}}$ & $86.0^{\mathrm{b}}$ & $84.0^{\mathrm{bc}}$ & $81.0^{\mathrm{bc}}$ & $56.0^{\mathrm{e}}$ & $63.0^{\mathrm{d}}$ & $68.0^{\mathrm{d}}$ & $86.0^{\mathrm{b}}$ & 2.6 \\
\hline Glu & $79.0^{c}$ & $96.0^{\mathrm{a}}$ & $87.0^{\mathrm{b}}$ & $87.0^{\mathrm{b}}$ & $92.0^{\mathrm{ab}}$ & $92.0^{\mathrm{ab}}$ & $63.0^{\mathrm{e}}$ & $71.0^{\mathrm{d}}$ & $71.0^{\mathrm{d}}$ & $91.0^{\mathrm{ab}}$ & 2.6 \\
\hline Pro & $72.0^{\mathrm{e}}$ & $94.0^{\mathrm{a}}$ & $84.0^{\mathrm{cd}}$ & $88.0^{\mathrm{bc}}$ & $88.0^{\mathrm{bc}}$ & $90.0^{\mathrm{ab}}$ & $60.0^{\mathrm{f}}$ & $72.0^{\mathrm{e}}$ & $81.0^{\mathrm{d}}$ & $91.0^{\mathrm{ab}}$ & 2.3 \\
\hline Gly & $70.0^{\mathrm{d}}$ & $94.0^{\mathrm{a}}$ & $82.0^{\mathrm{bc}}$ & $85.0^{\mathrm{bc}}$ & $80.0^{c}$ & $79.0^{\mathrm{c}}$ & $52.0^{\mathrm{f}}$ & $63.0^{\mathrm{e}}$ & $69.0^{\mathrm{de}}$ & $88.0^{\mathrm{ab}}$ & 2.8 \\
\hline Ala & $68.0^{\mathrm{f}}$ & $95.0^{\mathrm{a}}$ & $77.0^{\text {de }}$ & $84.0^{\mathrm{bc}}$ & $89.0^{\mathrm{ab}}$ & $78.0^{\text {cd }}$ & $76.0^{\text {de }}$ & $77.0^{\text {cde }}$ & $71.0^{\text {ef }}$ & $86.0^{\mathrm{b}}$ & 2.8 \\
\hline Cys & $74.0^{\mathrm{d}}$ & $93.0^{\mathrm{ab}}$ & $88.0^{\mathrm{b}}$ & $89.0^{\mathrm{ab}}$ & $91.0^{\mathrm{ab}}$ & $91.0^{\mathrm{ab}}$ & $59.0^{f}$ & $68.0^{\mathrm{e}}$ & $82.0^{\mathrm{b}}$ & $94.0^{\mathrm{a}}$ & 2.3 \\
\hline
\end{tabular}

a,b,c,d,e,f Means within a row with different subscripts differ $(P<0.05)$.

${ }^{1} \mathrm{MM}=$ Meat meal; $\mathrm{FM}$ = fish meal; $\mathrm{CSM}=$ cottonseed meal; $\mathrm{SBM}=$ soybean meal $; \mathrm{CG}=$ corn grain; $\mathrm{BG}=$ barley grain; $\mathrm{BH}=$ barley hay; $\mathrm{CS}=$ corn silage; $\mathrm{AH}=$ alfalfa hay; $\mathrm{WB}=$ wheat bran .

${ }^{2} \mathrm{EAA}=$ Essential AA; NEAA = nonessential AA.

after rumen incubation can be caused by the difference in degradation rates between individual AA. Differences in the degradation rates of individual AA might be dependent on the content of the different protein classes (albumin, globulin, etc.) in the feedstuffs and their respective physical properties (solubility, structure) and AA composition (Messman et al., 1992; Van Straalen et al., 1997). Unfortunately, insufficient data points were available to determine the actual rate of disappearance of individual AA in the rumen for the amount of the insoluble fraction that was degradable and influence on extent of disappearance of AA in the rumen (Ørskov and McDonald, 1979). Models used by the Agricultural and Food Research Council (1993) and NRC (2001) assume that the rates of disappearance of each individual AA in the rumen of cattle are similar.

\section{Intestinal Disappearance}

Because mobile nylon bags were recovered from the feces, the disappearance of DM, CP, and AA were calculated as the sum of their disappearance in the small intestine and large intestine. Although the latter was not measured in our experiment, other studies indicate that large intestine fermentation has only a limited effect on total intestinal disappearance, both in nylon bag (Voigt et al., 1985; Van Straalen et al., 1997) and in vivo experiments (Van Straalen and Tamminga, 1990). In contrast to many concentrates, a much smaller proportion of the initial forage $\mathrm{CP}$ was degraded in the intestine. This difference is probably a result of the leaf protein in forages being highly degradable in the rumen, and that much of the forages $\mathrm{CP}$ appearing in the small intestine is associated with the cell wall protein (i.e., stems) and therefore not readily available for digestion (Van Straalen and Tamminga, 1990).

Before determining intestinal degradability, all samples were preincubated in the rumen for $12 \mathrm{~h}$ based on the recommendations of De Boer et al. (1987), Hvelplund et al. (1992), and Von Keyserlingk et al. (1996). It has been well established that preincubation significantly increases the total disappearance of protein in the intestine compared with samples without preincubation (Hvelplund et al., 1992). Whether the 12-h preincubation time in the rumen, as recommended by De Boer et al. (1987), before insertion into the duodenal cannula is representative of actual rumen retention time is questionable. Varvikko and Vanhatalo (1991) preincubated forage samples for $16 \mathrm{~h}$ and stated that this time interval was probably too short. De Boer et 
al. (1987) assumed that rumen incubation of both cereals and alfalfa hay for $8 \mathrm{~h}$ reflected rumen residence time. Although an 8-h residence time may be appropriate for the cereal grains, it is questionable whether it is long enough for forages. If rumen retention time were indeed longer than $12 \mathrm{~h}$, the actual intestinal disappearance values would be lower than those presented in Table 4.

The intestinal disappearance of $\mathrm{CP}$ in the most cases was high compared with that of DM. The failure to treat the mobile nylon bags with abomasal pepsin- $\mathrm{HCl}$ following rumen preincubation must be addressed. Although not using pepsin-HCl incubation, Voigt et al. (1985) observed similar intestinal digestibilities to the results of Van Straalen et al. (1993), who did use pepsin$\mathrm{HCl}$ incubation. The percentage $\mathrm{CP}$ escaping rumen degradation (RUP) that is subsequently available for digestion in the small intestine was also variable in a number of cases. The National Research Council (2001) reported a RUP value $35.3 \%$ for corn silage based on 3 determinations. A value of $44 \%$ (disappearance in total tract - disappearance in rumen) was observed in this experiment. The National Research Council (2001) reported a value for rumen undegradability of $\mathrm{CP}$ of $40.9 \%$ for alfalfa, which is slightly lower than the value calculated for intestinal disappearance (36\%) in this experiment. It is clear that incorporating a forage containing $36 \%$ RUP into a ration will result in a very different ration than incorporating a forage containing $40.9 \%$ RUP.

For all feedstuffs, intestinal incubation had a considerable effect on the AA profile. For most feedstuffs, this could be explained by the relatively high disappearance of Arg and low disappearance of Gly. Thus, these AA largely accounted for the difference between the intestinal disappearance of EAA and NEAA. The high disappearance of Arg could be the result of the action of trypsin (EC 3.4.21.4), an endopeptidase that hydrolyzes only Lys and Arg bonds (Stryer, 1988; Van Straalen et al., 1997). Le Henaff et al. (1988), however, did not find higher Arg disappearance in the intestine. The low disappearance of Gly might be an indication of contamination with endogenous protein, which has a high Gly content (Van Straalen et al., 1997).

\section{Disappearance in Total Tract}

The total tract disappearance value for alfalfa was slightly higher than in vivo digestibility results reported by Von Keyserlingk and Mathison (1989). This could be expected, because the mobile nylon bag technique gives an estimate of true digestibility (De Boer et al., 1987; Von Keyserlingk et al., 1996) rather than apparent digestibility, which is obtained using conven- tional in vivo digestibility determinations. The disappearance value of CP $(87 \%)$ for alfalfa was similar to reported values $(88.4 \%)$, but the disappearance value for CS (73\%) was lower than that reported (84.82\%) by Von Keyserlingk et al. (1996). The total tract disappearance values of DM, CP, AA, EAA, NEAA, and individual AA for FM were slightly higher than the other feedstuffs, indicating the potential of this protein supplement to supply a higher proportion of AA absorbed in the intestine. The results of the current study indicated that feedstuffs with lower ruminal disappearance such as MM and FM was generally compensated for by higher intestinal disappearance, resulting in a relatively constant total tract disappearance. This compensation also explains the variation of ruminal CP disappearance with incubation time of feedstuffs in the rumen (De Boer et al., 1987; Van Straalen et al., 1993) in accordance with the hypothesis of Hvelplund et al. (1992) that each feedstuff contains a CP fraction that is undegradable in both the rumen and intestine. These findings also suggest that the intestine has an excess capacity to digest protein.

\section{CONCLUSIONS}

Within a feedstuff, lower ruminal disappearance of DM, CP, and AA was compensated for by higher intestinal disappearance, resulting in a small variation in total tract disappearance, thus validating the assumption that protein in a feedstuff contains fractions that are undegradable in both the rumen and the intestine (Kohn and Allen, 1992; Van Straalen et al., 1993). Individual AA in feedstuffs disappeared at different rates in the rumen and in the intestinal tract. Consequently, the proportion of feedstuffs protein and AA entering the intestine must be considered.

\section{ACKNOWLEDGMENTS}

This experiment was carried out at the dairy barn of University of Ferdowsi, Iran. The authors thank Rana Noori, Asad Teimouri, Moslem Bashtani, A. Mahdavi, and $\mathrm{H}$. Heydarian for their assistance, and the staff of the dairy unit for cares of the steers and sample collection. The authors thank Homayoun Zahiroddini for his assistance, and Darrell Vedres for the AA analysis of test feeds.

\section{REFERENCES}

Abu-Ghazealeh, A. A., D. J. Schingoethe, and A. R. Hippen. 2001. Blood amino acids and milk composition from cows fed soybean meal, fish meal or both. J. Dairy Sci. 84:1174-1181.

Agricultural and Food Research Council. 1993. Energy and Protein Requirement of Ruminants. An Advisory Manual Prepared by 
the AFRC Technical Committee on Responses to Nutrients. G. Alderman and B. R. Cottrill, ed. CAB Int., Wallingford, UK.

Bidlinger, B. A., S. A. Cohen, and T. L. Tarvin. 1984. Rapid analysis of amino acids using pre-column derivatization. J. Chromatogr. 336:93-104.

Chiou, P. W. S., K. Kuo, J. Hsu, and B. Yu. 1995. Studies on the protein degradabilities of feedstuffs in Taiwan. Anim. Feed Sci. Technol. 55:215-226.

De Boer, G., J. J. Murphy, and J. J. Kennelly. 1987. Mobile nylon bag for estimating intestinal availability of rumen undegradable protein. J. Dairy Sci. 70:977-982.

Goering, H. K., and P. J. Van Soest. 1970. Forage Fiber Analyses (Apparatus, Reagents, Procedures, and Some Applications). Agric. Handbook No. 379. ARS-USDA, Washington, DC.

Hagen, S. R., B. Frost, and J. Augustin. 1989. Pre-column phenylisothiocyanate derivatization and liquid chromatography of amino acids in food. J. AOAC 72:912-916.

Harstad, O. M., and E. Prestløkken. 2001. Rumen degradability and intestinal indigestibility of individual amino acids in corn gluten meal, canola meal and fish meal determined in situ. Anim. Feed Sci. Technol. 94:127-135.

Hvelplund, T., M. R. Weisbjerg, and L. S. Anderson. 1992. Estimation of the true digestibility of rumen undegraded dietary protein in the small intestine of ruminants by the mobile nylon bag technique. Acta Agric. Scand. 42:34-39.

Kohn, R. A., and M. S. Allen. 1992. Storage of fresh and ensiled forages by freezing affects fiber and crude protein fractions. J. Sci. Food Agric. 58:215-220.

Le Henaff, L., H. Rulquin, and J. L. Peyraud. 1988. A study of amino acid disappearance from feedstuffs in the rumen and intestine measured with the nylon bag method. Reprod. Nutr. Dev. 28(Suppl. 1):133-134.

Messman, M. A., W. P. Weiss, and D. O. Erickson. 1992. Effect of nitrogen fertilization and maturity of bromegrass on nitrogen and amino acid utilization by cows. J. Anim. Sci. 70:566-575.

National Research Council. 2001. Nutrient Requirements of Dairy Cattle. 7th rev. ed. Natl. Acad. Sci., Washington, DC.

Ørskov, E. R., and I. McDonald. 1979. The estimation of protein degradability in the rumen from incubation measurement weighted according to rate of passage. J. Agric. Sci. (Camb.) 92:499-503.

Piepenbrink, M. S., and D. J. Schingoethe. 1998. Ruminal degradation, amino acid composition, and estimated intestinal digestibilities of four protein supplements. J. Dairy Sci. 81:454-461.

Rooke, J. A. 1985. The nutritive value of feed proteins and feed protein residues resistant to degradation by rumen microorganisms. J. Sci. Food Agric. 36:629-637.
Rulquin, H., and R. Verite. 1993. Amino acid nutrition and dairy cows: Productive effects and animal requirements. Pages 55-77 in Recent Advances in Animal Nutrition. P. C. Garnsworthy and D. J. A. Cole, ed. Nottingham University Press, Loughborough, UK.

SAS Institute. 1990. SAS User's Guide: Statistics, version 6, 4th ed. 1990. SAS Inst., Inc., Cary, NC.

Schwab, C. G., C. K. Bozak, N. L. Whitehouse, and M. M. A. Mesbah. 1992. Amino acid limitation and flow to duodenum at four stages of lactation. 1. Sequence of lysine and methionine limitation. J. Dairy Sci. 75:3486-3502.

Stryer, L. 1988. Biochemistry. Freeman and Company, New York, NY

Susmel, P., B. Stefanon, C. R. Mills, and M. Candido. 1989. Change in amino acid composition of different protein sources after rumen incubation. Anim. Prod. 49:375-385.

Van Straalen, W. M., F. M. H. Dooper, A. M. Antoniewicz, I. Kosmala, and A. M. Van Vuuren. 1993. Intestinal digestibility of protein from grass and clover in dairy cows measured with the mobile nylon bag and other methods. J. Dairy Sci. 70:977-982.

Van Straalen, W. M., J. J. Odiga, and W. Mostert. 1997. Digestion of feed amino acids in the rumen and small intestine of dairy cows measured with nylon-bag techniques. Br. J. Nutr. 77:83-97.

Van Straalen, W. M., and S. Tamminga. 1990. Protein degradation of ruminant diets. Page 55 in Feedstuff Evaluation. J. Wiseman and D. J. A. Cole, ed. Butterworths, London, UK.

Varvikko, T., J. E. Lindberg, J. Setala, and L. Syrjala-Qvist. 1983. The effect of formaldehyde treatment of soya-bean meal and rapeseed meal on amino acid profiles and acid-pepsin solubility of rumen undegraded protein. J. Agric. Sci. (Camb.) 101:603-612.

Varvikko, T., and A. Vanhatalo. 1991. Intestinal nitrogen of hay and grass silage estimated by the mobile nylon bag technique. World Rev. Anim. Prod. 16:73-76.

Voigt, J., B. Piatkowski, H. Englelman, and E. Rudolph. 1985. Measurement of postrumen digestibility of crude protein by the technique in cows. Arch. Tierernahr. 35:555-562.

Von Keyserlingk, M. A. G., and G. W. Mathison. 1989. Use of the in situ technique and passage rate constants in predicting voluntary intake and apparent digestibility of forages by steers. Can. J. Anim. Sci. 69:973-987.

Von Keyserlingk, M. A. G., J. A. Shelford, R. Puchala, M. L. Swift, and L. Fisher. 1998. In situ disappearance of amino acids from grass silage in the rumen and intestine of cattle. J. Dairy Sci. 81:140-149.

Von Keyserlingk, M. A. G., M. L. Swift, R. Puchala, and J. A. Shelford. 1996. Degradability characteristics of dry matter and crude protein of forages in ruminant. Anim. Feed Sci. Technol. 57:291-311. 